\title{
Determination of Infective Dose of H9N2 Avian Influenza Virus in Different Routes: Aerosol, Intranasal, and Gastrointestinal
}

\author{
Meiling Yao ${ }^{a, b}$ Jing Lv ${ }^{c, d}$ Rong Huang ${ }^{b, e}$ Yan Yang ${ }^{b}$ Tongjie Chai ${ }^{b, d}$ \\ ${ }^{a}$ Zaozhuang Vocational College, ${ }^{b}$ College of Animal Science and Veterinary Medicine, Shandong Agricultural \\ University, 'Tai'an Municipal Center for Disease Control and Prevention, and ${ }^{\mathrm{d} C o l l e g e}$ of Life Sciences, \\ Shandong Agricultural University, Shandong, and e Department of Medical Tests, Xinxiang Medical University, \\ Xinxiang, PR China
}

\section{Key Words}

H9N2 avian influenza virus · Infective dose · Aerosol infection · Chickens

\begin{abstract}
Background: Low pathogenic H9N2 avian influenza virus (AIV) has been spreading worldwide, leading to huge economic losses to poultry husbandry, but few studies were concerned about its aerosol infection. Methods: This study compared the infective doses of H9N2 AIV to chickens by three different routes, aerosol infection, intranasal and gastrointestinal infection, and determination of the results was conducted by detecting virus shedding and seroconversion of chickens. Results: The results indicated that chickens were susceptible to H9N2 AIV with a different infection rate which depended on the route of inoculation. H9N2 AIV media aerosol-infective dose $\left(\mathrm{alD}_{50}\right)$ to chickens was about $491 \mathrm{TCID}_{50}$, intranasal infection was $398 \mathrm{TCID}_{50}$, and gastrointestinal infection was $19,952 \mathrm{TCID}_{50}$. Conclusion: The infection ability of H9N2 AIV to chickens was related to its way of invading. The respiratory infection ability was about 40 times more effective than gastrointestinal infection, which suggested that urgent attention should be paid to environmental disinfection to block airborne transmission of influenza virus.
\end{abstract}

\section{KARGER}

E-Mail karger@karger.com

www.karger.com/int

\section{Introduction}

H9N2 avian influenza virus (AIV) is a low pathogenic virus of the family Orthomyxoviridae, but it has caused high morbidity and mortality to poultry when coinfected with other pathogens $[1,2]$. Notably, cases of humans infected with H9N2 AIV have been reported in Hong Kong and mainland China since the late 1990s [3, 4]. Studies have demonstrated that influenza viruses can be transmitted in mammals by aerosols and also be detected in the air of an emergency department [5-7]. In addition, recent studies found that an amino acid mutation from glutarnine (Gln, Q) to leucine (Leu, L) at position 226 of hemagglutinin (HA) enabled H9N2 AIV to bind to human-like receptors. Also, transmission research demonstrated that L226-containing H9N2 AIV was able to replicate in mammals without adaption and transmit by direct contact $[8,9]$. A further study showed that this virus reassorted with human $\mathrm{H} 3 \mathrm{~N} 2$ backbone could transmit efficiently via respiratory droplets [10]. Recent studies have indicated that the main reason for H9N2 AIV spreading widely among domestic poultry in China after 1998 was its airborne transmissibility [11].

M.Y. and J.L. contributed equally to this work. 
Airborne transmission was an important fact for the spread of AIV and was difficult to control, so it should be taken into consideration in eradication strategies [12].

There are usually three different routes, aerosol inhaling, intranasal and gastrointestinal contact, for AIV to infect animals [13]. H9N2 AIV could transmit in poultry by aerosols, but most experiments used intranasal inoculation to study the pathogenicity of this virus $[2,9-11]$. It has been demonstrated that a low infective dose of human influenza virus was required for a viral aerosol to infect volunteers, and H9N2 AIV aerosols could infect mammals at certain concentrations [14, 15]. However, few studies were concerned about the H9N2 AIV aerosol-infective dose to chickens which would have been a guide for poultry disease control. Trying to emulate natural exposure, in this study, using different infection routes to inoculate chickens, we found that respiratory infection was a more efficient route than gastrointestinal infection for H9N2 AIVs to infect chickens.

\section{Materials and Methods}

Virus and Cells

A/Chicken/Shandong/01/2008 H9N2 AIVs (GenBank accession No. HQ326722) were propagated using 9-day-old specific pathogen-free (SPF) chicken embryos according to the method described by Office International des Epizooties (OIE) and stored at $-70^{\circ}$. The $\mathrm{TCID}_{50}$ of virus was determined in Madin-Darby canine kidney (MDCK) cells and calculated using the methods of Reed and Muench [16]. Cells were separately maintained in Dulbecco's minimum essential medium (Gibco) supplemented with $10 \%$ fetal calf sera, 100 units $/ \mathrm{ml}$ penicillin, $100 \mathrm{mg} / \mathrm{ml}$ streptomycin and incubated at $37^{\circ}$ with $5 \% \mathrm{CO}_{2}$.

\section{Facility}

Studies on H9N2 AIV were conducted in a biosecurity level 2+ laboratory approved by the China National Accreditation Service for Conformity Assessment. SPF white leghorn chickens (Chinese Academy of Agricultural Sciences) used in this study were treated strictly according to the guidelines of Laboratory Animal Management from National Council for Science and Technology, and fed in SPF isolators (Tianjin Jinhang Pure Air Condition Engineering Co., China) with a volume of about $1 \mathrm{~m}^{3}$ (length $180 \mathrm{~cm}$, width 70 $\mathrm{cm}$, height $90 \mathrm{~cm}$ ) and with an airflow rate of $0.1 \mathrm{~m} / \mathrm{s}$. The environmental conditions for the chickens were at $20-22^{\circ}$ and $45-50 \%$ relative humidity.

\section{Aerosol Infection}

The H9N2 AIV viral solution was 10 -fold diluted $\left(10^{6.69}\right.$ $10^{2.69} \mathrm{TCID}_{50} / \mathrm{ml}$ ), and then viral aerosols (particle diameter 3-5 $\mu \mathrm{m})$ were nebulized to the isolators using a TK-3-type microbial aerosol generator (Liaoning Kangjie Instrument Research Insti- tute, China) with $3 \mathrm{ml}$ viral solution. 10 SPF chickens of every group were exposed for $15 \mathrm{~min}(\mathrm{t})$ and then transferred with separate wire cages to clean isolators. Swab samples were collected 3 and 5 days postinfection (dpi) and inoculated in MDCK cells. Determination was conducted using the standard HA assay. The average respiratory volume of chicken is 42.5 liters $\mathrm{kg}^{-1}$ $\mathrm{h}^{-1}$, therefore the inhaled volume $\left(\mathrm{V}_{\mathrm{i}}\right)$ is $42.5 \times \mathrm{w}$ liters $\mathrm{h}^{-1}$ [w, weight $(\mathrm{kg})] . \mathrm{D}_{\mathrm{i}}=\mathrm{C} \times \mathrm{t} \times \mathrm{V}_{\mathrm{i}}\left(\mathrm{D}_{\mathrm{i}}\right.$, total infective dose; $\mathrm{C}$, aerosol concentration) $[17,18]$. The aID $_{50}$ (aerosol median infective dose) was calculated using the Bliss method (weighted regression method) and analyzed using SPSS version 11.5 software (Statistical Package for the Social Science, Inc., Chicago, Ill., USA).

\section{Intranasal and Gastrointestinal Infection}

A series of 10-fold diluted H9N2 AIVs $\left(10^{4.69}-10^{0.69}\right.$ TCID $\left._{50}\right)$ were used to infect 10 SPF chickens respectively intranasally with a volume of $100 \mu \mathrm{l}$. 10 SPF chickens were inoculated gastrointestinally with $10^{5.69}-10^{1.69} \mathrm{TCID}_{50}$ of $\mathrm{H} 9 \mathrm{~N} 2$ AIVs respectively in a volume of $1 \mathrm{ml}$. Briefly, the chicken crest was grasped by the left thumb and index finger and its beak was opened by pressing the head fall slightly upward to the outside. Virus suspension was dropped into the beak for gastrointestinal infection.

\section{Statistical Analysis}

The chickens infected by H9N2 AIVs were fed in SPF isolators and observed for 14 days. Oral swab samples were collected on 3 and $5 \mathrm{dpi}$ and put into $1 \mathrm{ml}$ sterilized PBS (0.1 M, pH 7.2). The supernatant was filtered with a Millex syringe filter with a pore diameter of $0.22 \mu \mathrm{m}$ and inoculated in MDCK cells within $72 \mathrm{~h}$. Determination was conducted using the standard HA assay. Sera samples were collected on 7 and $14 \mathrm{dpi}$ and seroconversion was confirmed by standard hemagglutination inhibition (HI) assay. Chickens with $\mathrm{HI}$ titers $<4$ were considered 'influenza-free'. The $\mathrm{ID}_{50}$ of intranasal and gastrointestinal infection was calculated using the methods of Reed and Muench [16].

\section{Results}

\section{Infective Dose of Viral Aerosol}

H9N2 viral aerosols were nebulized using a TK-3-type microbial aerosol generator and the aerosol concentration of every group was about $3 \times 10^{3.69}-3 \times 10^{-0.31}$ $\mathrm{TCID}_{50} /$ liter. The aerosol dose delivered to chickens was about 42,151.59-4.22 $\mathrm{TCID}_{50}$ through calculation (table 1). Oral swab samples of 10 chickens of every group were detected, cultured in MDCK cells and analyzed by HA assay. Results showed that 10 chickens were all infected when the aerosol dose was $42,151.59$ TCID $_{50}$ and only 1 chicken was infected when it was $43.71 \mathrm{TCID}_{50}$. The Bliss-weighted regression method indicated that H9N2 AIV media aerosol-infective dose $\left(\mathrm{aID}_{50}\right)$ to chickens was 491.21 TCID ${ }_{50}$. Seroconversion was detected in infected chickens on 14 dpi with anti-H9 antibody titers (HI titers) of 16-128. 
Table 1. Results of aerosol $\mathrm{ID}_{50}$ to SPF chickens of H9N2 AIVs

\begin{tabular}{|c|c|c|c|c|c|c|c|}
\hline 1 & $10^{0}$ & $10^{6.69}$ & $3 \times 10^{3.69}$ & 0.27 & $42,151.59$ & $10 / 10$ & 99.62 \\
\hline 2 & $10^{-1}$ & $10^{5.69}$ & $3 \times 10^{2.69}$ & 0.25 & $3,902.93$ & $9 / 10$ & 89.27 \\
\hline 3 & $10^{-2}$ & $10^{4.69}$ & $3 \times 10^{1.69}$ & 0.25 & 390.29 & $4 / 10$ & 44.52 \\
\hline 4 & $10^{-3}$ & $10^{3.69}$ & $3 \times 10^{0.69}$ & 0.28 & 43.71 & $1 / 10$ & 7.38 \\
\hline
\end{tabular}

a Total infective dose $\left(D_{\mathrm{i}}\right)=$ aerosol concentration $(\mathrm{C}) \times$ average respiratory volume $\left(42.5\right.$ liters kg $\left.\mathrm{kg}^{-1}\right) \times$ weight $(\mathrm{w}) \times$ exposure $^{-1}$ time $(\mathrm{t})$.

${ }^{\mathrm{b}}$ Oral swab samples of 10 chickens of every group were collected on 3 and 5 dpi and cultured in MDCK cells. They were tested by standard HA assay.

${ }^{c}$ H9N2 AIV aerosol median infective dose $\left(\mathrm{aID}_{50}\right)$ was $491.21 \mathrm{TCID}_{50}$ which was analyzed by Bliss-weighted regression (SPSS 11.5$)$.

Table 2. Results of intranasal $\mathrm{ID}_{50}$ to SPF chickens of H9N2 AIVs

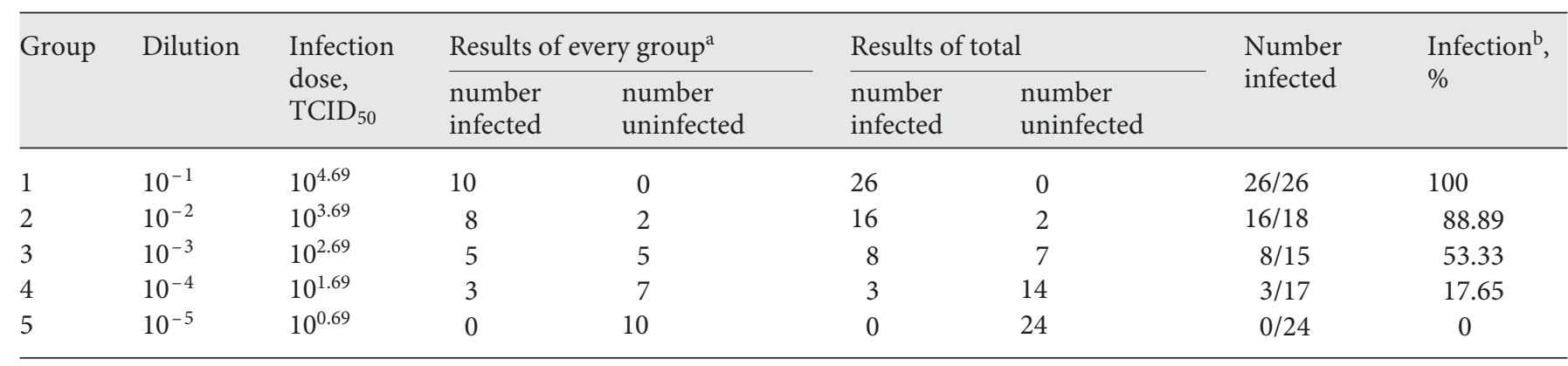

a Ten chickens of every group were inoculated intranasally and oral swab samples of every chicken were collected on 3 and 5 dpi and cultured in MDCK cells. They were tested by standard HA assay.

${ }^{\mathrm{b}} \mathrm{H} 9 \mathrm{~N} 2 \mathrm{AIV}$ intranasal $\mathrm{ID}_{50}$ was $398.11 \mathrm{TCID}_{50}$ which was calculated using the methods of Reed and Muench [16].

\section{Infective Dose of Intranasal Infection}

Ten chickens of every group were inoculated intranasally by $10^{4.69}-10^{0.69}$ TCID $_{50}$ of H9N2 AIVs (table 2 ). Results indicated that virus shedding could be detected from all inoculated chickens when they were infected by $10^{4.69}$ TCID $_{50}$, but no virus shedding was detected from chickens which were inoculated by $10^{0.69} \mathrm{TCID}_{50}$. The media intranasal infective dose of H9N2 AIV to chickens was 398.11 TCID $_{50}$, which was similar to the aerosol-infective dose. Seroconversion occurred in infected chickens on 14 dpi with HI titers of 16-128.

\section{Infective Dose of Gastrointestinal Infection}

Ten chickens of every group were inoculated gastrointestinally by $10^{5.69}-10^{1.69}$ TCID $_{50}$ of H9N2 AIVs (table 3 ). Results showed that virus shedding could be detected from all chickens when they were infected by $10^{5.69}$

Infective Dose of H9N2 Avian Influenza Virus
$\mathrm{TCID}_{50}$, but no virus was isolated from chickens that were inoculated by $10^{1.69} \mathrm{TCID}_{50}$. The media gastrointestinal infective dose of H9N2 AIV to chickens was 19,952.62 TCID $_{50}$, which was about 40 times that of the aerosolinfective dose. The infected chickens also had seroconversion with $\mathrm{HI}$ titers of 16-64 on $14 \mathrm{dpi}$.

\section{Clinical Symptoms}

All the chickens inoculated by these three methods appeared normally on $1 \mathrm{dpi}$, but they began to decrease feed intake, followed by depression, loss of feathers, nutation and necking on 2 or $3 \mathrm{dpi}$. The head and face of several chickens were swollen, and combs had dark purple edges, were thickened and hard, and by touching showed signs of fever. Scaly legs indicated symptoms of bleeding spots. Chickens with mild respiratory symptoms such as cough had difficulty breathing. Some of 
Table 3. Results of gastrointestinal $\mathrm{ID}_{50}$ to SPF chickens of H9N2 AIVs

\begin{tabular}{|c|c|c|c|c|c|c|c|c|}
\hline \multirow[t]{2}{*}{ Group } & \multirow[t]{2}{*}{ Dilution } & \multirow{2}{*}{$\begin{array}{l}\text { Infection } \\
\text { dose, } \\
\text { TCID }_{50}\end{array}$} & \multicolumn{2}{|c|}{ Results of every group ${ }^{a}$} & \multicolumn{2}{|c|}{ Results of total } & \multirow{2}{*}{$\begin{array}{l}\text { Number } \\
\text { infected }\end{array}$} & \multirow{2}{*}{$\begin{array}{l}\text { Infection }^{b} \\
\%\end{array}$} \\
\hline & & & $\begin{array}{l}\text { number } \\
\text { infected }\end{array}$ & $\begin{array}{l}\text { number } \\
\text { uninfected }\end{array}$ & $\begin{array}{l}\text { number } \\
\text { infected }\end{array}$ & $\begin{array}{l}\text { number } \\
\text { uninfected }\end{array}$ & & \\
\hline 1 & $10^{-1}$ & $10^{5.69}$ & 10 & 0 & 19 & 0 & $19 / 19$ & 100 \\
\hline 2 & $10^{-2}$ & $10^{4.69}$ & 6 & 4 & 9 & 4 & $9 / 13$ & 69.23 \\
\hline 3 & $10^{-3}$ & $10^{3.69}$ & 2 & 8 & 3 & 12 & $3 / 15$ & 20.00 \\
\hline
\end{tabular}

\footnotetext{
a Ten chickens of every group were inoculated gastrointestinally and oral swab samples of every chicken were collected on 3 and 5 dpi and cultured in MDCK cells. They were tested by standard HA assay.

${ }^{\mathrm{b}}$ H9N2 AIV gastrointestinal ID $_{50}$ was $19,952.62$ TCID $_{50}$ which was calculated using the methods of Reed and Muench [16].
}

them had diarrhea with watery, yellow-white or lightgreen stools. Clinical symptoms began to improve after 10 dpi. The uninfected chickens appeared normal during the experiments and no symptoms of disease were found in the control group.

\section{Discussion}

Naturally, influenza virus invades the host mainly via the respiratory and digestive tracts, and previous studies have indicated that they can be transmitted among animals by aerosols [13]. Influenza virus aerosols could generate during the course of an acute infection to pigs and temporal dynamics of this virus was closely associated with nasal shedding of infected pigs [19]. Influenza viruses could transmit in mammals and humans by aerosols, and healthcare professionals were easily infected within $1.829 \mathrm{~m}$ away from patients who released airborne influenza virus into the air by breathing, coughing and sneezing $[5,6,20]$. The median aerosol-infective dose of human influenza virus $\left(\mathrm{HID}_{50}\right)$ detected previously was about 0.6-3 TCID $_{50}$ [15], but little is known about aerosol-infective doses of H9N2 AIV which has caused enormous economic losses in poultry, especially in China [21, 22].

Poultry might be infected by different routes with AIVs. A previous study demonstrated that the result of infection was similar after ducks were inoculated with H5N1 AIV by three routes (intranasal, intracloacal, or intraocular) [23], but H9N2 AIV could cause more serious pathogenicity to chickens by trachea inoculation than by vein inoculation with the same dose [24]. However, most of the experiments used the intranasal inocu- lation route to study the characteristics of H9N2 AIV [2, $9,10]$. Many studies indicated that H9N2 AIV could infect poultry by aerosols and virus aerosols were detected from the air of animal houses, but the inhalation-infective process and aerosol-infective dose were still unclear $[11,25,26]$. Therefore, in addition to the intranasal and gastrointestinal inoculation route, we also designed an aerosol inoculation route which was similar to natural exposure to compare an H9N2 AIV-infective dose to chickens. Our study demonstrated that each route needed a different dose to infect chickens, and the media-infective dose of aerosol infection was similar to that of intranasal infection, but they were about 40 times more effective than that of gastrointestinal infection. The results indicated that respiratory infection of AIV was highly efficient.

Infection and transmission of the influenza virus were not only concerned with the characteristic of pathogens and hosts but also related to the environmental conditions such as temperature and relative humidity. The environmental conditions in our experiment were with 20$22^{\circ}$ and $45-50 \%$ relative humidity which enabled an influenza virus with high infectious ability $[27,28]$. Microbial aerosol particle size range is generally $1-100 \mu \mathrm{m}$ and larger particles may suspend for a few seconds, but the settling velocity of smaller aerosol particles is very slow. Studies indicated that particles with an aerodynamic diameter of $5 \mu \mathrm{m}$ needed $67 \mathrm{~min}$ to drop from a height of $3 \mathrm{~m}$ in a static environment through calculation of Stokes' law and these particles were able to enter as far as the alveolus [13]. In this study, nebulized aerosol particle diameter was 3-5 $\mu \mathrm{m}$ and $15 \mathrm{~min}$ was taken to exposure chickens, so viral aerosols could completely invade the trachea and alveoli cells and bind to the influenza recep- 
tor. Our study indicated that the $\mathrm{ID}_{50}$ of aerosol infection was a little higher than intranasal infection, which was probably due to the nebulized small particles being easily exhaled, although they could reach as far as the alveoli. Maybe it was relevant to the different distribution of influenza SAa2,3-Gal and SA 2,6-Gal receptors in chicken tracheal epithelial cells and alveoli, and a different capacity of virus binding to these receptors $[29,30]$. To better understand the difference between aerosol and intranasal infection, further studies on H9N2 AIV binding to receptors are needed. In conclusion, respiratory infection of H9N2 AIV had a higher efficiency than gastrointestinal infection, and chickens could be infected at a cer- tain concentration of viral aerosols, so more attention needs to be paid to environmental surveillance to prevent and control the airborne transmission of avian influenza.

\section{Acknowledgements}

This study was supported by the following foundation programs: National Science and Technology Support Project 'Key technology of animal health and breeding environmental control' (2012BAD39B02) and China Postdoctoral Science Foundation 'Molecular mechanism of H9N2 avian influenza virus airborne transmission' (2013M531639).

\section{References}

1 Nili H, Asasi K: Natural cases and an experimental study of H9N2 avian influenza in commercial broiler chickens of Iran. Avian Pathol 2002;31:247-252.

- 2 Haghighat-Jahromi M, Asasi K, Nili H, Dadras H, Shooshtari AH: Coinfection of avian influenza virus (H9N2 subtype) with infectious bronchitis live vaccine. Arch Virol 2008; 153:651-655.

-3 Peiris M, Yuen KY, Leung CW, Chan KH, Ip PL, Lai RW, Orr WK, Shortridge KF: Human infection with influenza H9N2. Lancet 1999; 354:916-917.

4 Butt KM, Smith GJ, Chen H, Zhang LJ, Leung YH, Xu KM, Lim W, Webster RG, Yuen KY, Peiris JS, Guan Y: Human infection with an avian H9N2 influenza A virus in Hong Kong in 2003. J Clin Microbiol 2005; 43:5760-5767.

5 Van Hoeven N, Pappas C, Belser JA, Maines TR, Zeng H, Garcia-Sastre A, Sasisekharan R, Katz JM, Tumpey TM: Human HA and polymerase subunit $\mathrm{PB} 2$ proteins confer transmission of an avian influenza virus through the air. Proc Natl Acad Sci USA 2009;106:33663371.

6 6 Munster VJ, de Wit E, van den Brand JM, Herfst S, Schrauwen EJ, Bestebroer TM, van de Vijver D, Boucher CA, Koopmans M, Rimmelzwaan GF, Kuiken T, Osterhaus AD, Fouchier RA: Pathogenesis and transmission of swine-origin $2009 \mathrm{~A}(\mathrm{H} 1 \mathrm{~N} 1)$ influenza virus in ferrets. Science 2009;325:481483.

7 Blachere FM, Lindsley WG, Pearce TA, Anderson SE, Fisher M, Khakoo R, Meade BJ, Lander O, Davis S, Thewlis RE, Celik I, Chen BT, Beezhold DH: Measurement of airborne influenza virus in a hospital emergency department. Clin Infect Dis 2009;48:438-440.
-8 Matrosovich MN, Krauss S, Webster RG: H9N2 influenza A viruses from poultry in Asia have human virus-like receptor specificity. Virology 2001;281:156-162.

$\checkmark 9$ Wan H, Sorrell EM, Song H, Hossain MJ, Ramirez-Nieto G, Monne I, Stevens J, Cattoli G, Capua I, Chen LM, Donis RO, Busch J, Paulson JC, Brockwell C, Webby R, Blanco J, Al-Natour MQ, Perez DR: Replication and transmission of H9N2 influenza viruses in ferrets: evaluation of pandemic potential. PLoS One 2008;3:e2923.

10 Sorrell EM, Wan H, Araya Y, Song H, Perez DR: Minimal molecular constraints for respiratory droplet transmission of an avian-human H9N2 influenza A virus. Proc Natl Acad Sci USA 2009;106:7565-7570.

11 Shi H, Ashraf S, Gao S, Lu J, Liu X: Evaluation of transmission route and replication efficiency of H9N2 avian influenza virus. Avian Dis 2010;54:22-27.

12 Landman WJ, Schrier CC: Avian influenza: eradication from commercial poultry is still not in sight (in Dutch). Tijdschr Diergeneeskd 2004;129:782-796.

13 Tellier R: Aerosol transmission of influenza A virus: a review of new studies. J R Soc Interface 2009;6(suppl 6):S783-S790.

14 Lv J, Wei B, Yang Y, Yao M, Cai Y, Gao Y, Xia $X$, Zhao X, Liu Z, Li X, Wang H, Yang H, Roesler U, Miao Z, Chai T: Experimental transmission in guinea pigs of $\mathrm{H} 9 \mathrm{~N} 2$ avian influenza viruses from indoor air of chicken houses. Virus Res 2012;170:102-108.

15 Alford RH, Kasel JA, Gerone PJ, Knight V: Human influenza resulting from aerosol inhalation. Proc Soc Exp Biol Med 1966;122: 800-804.
16 Reed LJ, Muench H: A simple method of estimating fifty per cent endpoints. Am J Epidemiol 1938;27:493-497.

-17 MacInnes H, Zhou Y, Gouveia K, Cromwell J, Lowery K, Layton RC, Zubelewicz M, Sampath R, Hofstadler S, Liu Y, Cheng YS, Koster F: Transmission of aerosolized seasonal H1N1 influenza A to ferrets. PLoS One 2011; 6:e24448

18 Che FX, Chai TJ, Li JS: Principle and Application of Aerobiology. Beijing, Science Press, 2004.

19 Corzo CA, Romagosa A, Dee SA, Gramer MR, Morrison RB, Torremorell M: Relationship between airborne detection of influenza $A$ virus and the number of infected pigs. Vet J 2013;196:171-175.

20 Bischoff WE, Swett K, Leng I, Peters TR: Exposure to influenza virus aerosols during routine patient care. J Infect Dis 2013;207:10371046.

21 Liu H, Liu X, Cheng J, Peng D, Jia L, Huang Y: Phylogenetic analysis of the hemagglutinin genes of twenty-six avian influenza viruses of subtype H9N2 isolated from chickens in China during 1996-2001. Avian Dis 2003;47: 116-127.

22 Xu KM, Li KS, Smith GJ, Li JW, Tai H, Zhang JX, Webster RG, Peiris JS, Chen H, Guan Y: Evolution and molecular epidemiology of H9N2 influenza A viruses from quail in southern China, 2000 to 2005. J Virol 2007;81: 2635-2645.

23 Pantin-Jackwood M, Swayne DE, Smith D, Shepherd E: Effect of species, breed and route of virus inoculation on the pathogenicity of H5N1 highly pathogenic influenza (HPAI) viruses in domestic ducks. Vet Res 2013;44:62. 
24 Gao L, Tang W, Hu R, Chen X, Ma L, Gao S, Liu X: Impact of different routes of inoculations of the mild-pathogenic avian influenza virus upon the pathogenicity of this virus in SPF chickens. Chin J Zoonoses 2006;22:716719.

25 Yao M, Zhang X, Gao J, Chai T, Miao Z, Ma W, Qin M, Li Q, Li X, Liu J, Zhang H: The occurrence and transmission characteristics of airborne H9N2 avian influenza virus. Berl Munch Tierärztl Wochenschr 2011;124:136141.
26 Lv J, Wei B, Chai T, Xia X, Miao Z, Yao M, Gao Y, Huang R, Yang H, Roesler U: Development of a real-time RT-PCR method for rapid detection of $\mathrm{H} 9$ avian influenza virus in the air. Arch Virol 2011;156:1795-1802.

27 Lowen AC, Mubareka S, Steel J, Palese P: Influenza virus transmission is dependent on relative humidity and temperature. PLoS Pathog 2007;3:1470-1476.

28 Lowen AC, Steel J, Mubareka S, Palese P: High temperature $\left(30^{\circ} \mathrm{C}\right)$ blocks aerosol but not contact transmission of influenza virus. J Virol 2008;82:5650-5652.
Kuchipudi SV, Nelli R, White GA, Bain M, Chang KC, Dunham S: Differences in influenza virus receptors in chickens and ducks: implications for interspecies transmission. J Mol Genet Med 2009;3:143-151.

30 Pillai SP, Lee CW: Species- and age-related differences in the type and distribution of influenza virus receptors in different tissues of chickens, ducks and turkeys. Virol J 2010; $7: 5$. 